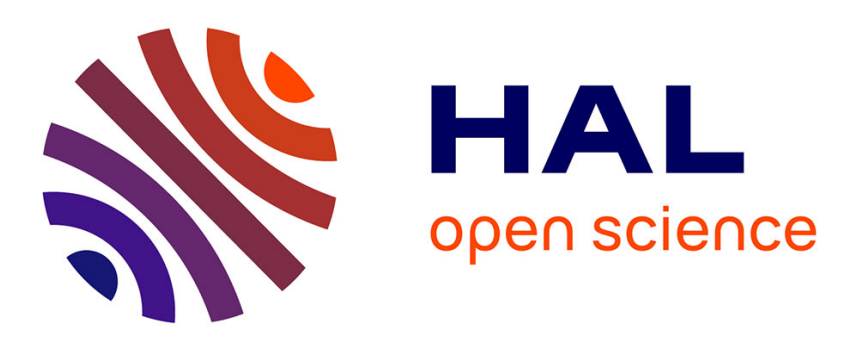

\title{
The dynamics of aroma compound transfer properties in cheeses during simulated eating conditions
}

Marion Doyennette, Isabelle Deleris, Anne Saint Eve, Aurélie Gasiglia, Isabelle Souchon, Cristian Trelea

\section{- To cite this version:}

Marion Doyennette, Isabelle Deleris, Anne Saint Eve, Aurélie Gasiglia, Isabelle Souchon, et al.. The dynamics of aroma compound transfer properties in cheeses during simulated eating conditions. Food Research International, 2011, 44 (10), pp.3174 - 3181. 10.1016/j.foodres.2011.07.034 . hal-01003263

\section{HAL Id: hal-01003263 \\ https://hal.science/hal-01003263}

Submitted on 28 Sep 2017

HAL is a multi-disciplinary open access archive for the deposit and dissemination of scientific research documents, whether they are published or not. The documents may come from teaching and research institutions in France or abroad, or from public or private research centers.
L'archive ouverte pluridisciplinaire HAL, est destinée au dépôt et à la diffusion de documents scientifiques de niveau recherche, publiés ou non, émanant des établissements d'enseignement et de recherche français ou étrangers, des laboratoires publics ou privés. 


\title{
The dynamics of aroma compound transfer properties in
}

\section{cheeses during simulated eating conditions}

\author{
M. Doyennette ${ }^{* 1,2}$, I. Déléris ${ }^{1,2}$, A. Saint-Eve ${ }^{2,1}$, A. Gasiglia ${ }^{1,2}$, I. Souchon ${ }^{1,2}$, I. C. Tréléa ${ }^{2,1}$ \\ ${ }^{1}$ INRA, UMR782, 78850 Thiverval Grignon, France \\ ${ }^{2}$ AgroParisTech, UMR782, 78850 Thiverval Grignon, France
}

\section{Abstract}

In vivo aroma release during solid food consumption is a complex phenomenon that depends on food structure and composition, as well as on oral processing (combination of mastication and incorporation of saliva into the food product). The objective of this study was to understand and to predict the physico-chemical properties of aroma compounds through the dynamics of flavor release during inmouth oral processing of food before bolus swallowing. Within this context, the evolution of two aroma compounds during bolus formation was explored by studying the two main properties that account for mass transfer: air/bolus partition and mass transfer coefficients. Four types of industrial cheese products (varying in fat and firmness) flavored with ethyl propanoate and 2-nonanone were chosen. Each matrix was mixed with various amounts of artificial saliva to mimic boluses at different stages of mastication. The air/bolus partition coefficient was determined by the static phase ratio variation method (PRV), while the mass transfer coefficient was obtained by non-linear regression from dynamic headspace experiments. Results showed that there is a dilution effect on the air/bolus partition coefficient and both a dilution and a product effect (firmness) on the mass transfer coefficient of ethyl propanoate in the bolus. These results were also validated with 2-nonanone for the low-fat cheeses.

\footnotetext{
${ }^{*}$ Corresponding author: Marion Doyennette, marion.doyennette@grignon.inra.fr; fax: +33 (0)1 30815597 
Keywords: model food bolus, air/bolus partition coefficient, mass transfer coefficient, artificial saliva, modeling, aroma compound

\section{Introduction}

When a solid food product is eaten, oral breakdown processing is required for the formation of a bolus ready to be swallowed. For brittle solids, mastication leads to the fragmentation of food into small individual particles. For cohesive foods such as cheeses, the chewing action and the mixing with saliva soften the material and change its rheological properties (Salles et al., 2011). Recent studies (Prinz \& Lucas, 1997; Tarrega, Yven, Sémon, \& Salles, 2011; van Der Bilt, Engelen, Abbink, \& Pereira, 2007; Claude Yven, Culioli, \& Mioche, 2005) have shown that saliva incorporation into the food bolus was an important factor in determining bolus texture and cohesion. More specifically, saliva plays a key role in parameters such as the plasticity, the good lubrication and the cohesiveness of the bolus, properties which trigger the reflex swallowing event (Woda, Mishellany, \& Peyron, 2006).

Saliva also plays a key role in flavor release during food consumption mainly by means of dilution or interaction effects with food ingredients (Buettner, 2002a, 2002b; Poinot, Arvisenet, Grua-Priol, Fillonneau, \& Prost, 2009). The influence of saliva on aroma release has been widely studied, both from in vivo and in vitro systems, with either real (Buettner, 2002a, 2002b; Genovese, Piombino, Gambuti, \& Moio, 2009; van Ruth \& Roozen, 2000) or artificial saliva (Friel \& Taylor, 2001; Genovese et al., 2009), and on various foods: water model solutions (Buettner, 2002a; Friel \& Taylor, 2001), oil model solutions (van Ruth, Grossmann, Geary, \& Delahunty, 2001), vegetables such as pepper and beans (van Ruth \& Roozen, 2000; van Ruth, Roozen, \& Cozijnsen, 1995; van Ruth, Roozen, Nahon, Cozijnsen, \& Posthumus, 1996), complex foods (Odake, Roozen, \& Burger, 1998) and wine (Genovese et al., 2009). . However, no general observation can be established because the effect of saliva may vary depending on the experimental conditions. It mainly depends on the aroma compound (Buettner, 2002a, 2002b), the artificial saliva composition (Friel \& Taylor, 2001; Genovese 
et al., 2009; Odake et al., 1998; van Ruth et al., 2001; van Ruth et al., 1996) and the dilution ratio (van Ruth et al., 2001). It also depends on the matrix studied (van Ruth \& Roozen, 2000) and the incubation time with the flavored food sample (from 1 minute to 3 hours, according to the literature).

In spite of variations during eating, saliva is mainly composed of water $(99.5 \%)$, proteins $(0.3 \%)$ including mucins and enzymes, and inorganic substances (0.2\%) (van Aken, Vingerhoeds, \& de Hoog, 2007). Different types of artificial saliva composition have been studied in the literature with in vitro experiments, and many publications (Genovese et al., 2009; Odake et al., 1998; van Ruth et al., 2001; van Ruth et al., 1996) refer to the composition proposed by van Ruth et al. (van Ruth et al., 1995). The effect of the type of mucin, and of the presence of salt on flavor release from sucrose solutions, have been investigated (Friel \& Taylor, 2001).. The authors found that the cheapest and most commonly used mucin (from pig stomach) was a suitable substitute for in vitro studies in terms of the effect on volatile release. Moreover, salivary salts seemed to cause a modification of the interactions between the aroma compound and the mucin by changing its conformational state. The importance of adding salts to artificial saliva was also highlighted by van Ruth et al. (van Ruth et al., 2001), who found that saliva cannot be replaced by water without altering phase equilibriums (for water and oil model systems).

Concerning the impact of saliva/product ratio on flavor release, results found in the literature are dependent on the type of food studied. For very low-fat foods such as vegetables, saliva acted like water and very weakly affected the air/product partition coefficients (van Ruth et al., 1996). For emulsion systems, on the contrary, an effect of saliva dilution was found as a result of the different solubilities and affinities of the compounds for the oil and the saliva phases (van Ruth et al., 2001). The authors also concurred on the greater importance of the saliva/product ratio with regard to saliva composition.

Only a few studies have investigated the combined effect of mastication and of saliva on the release of aroma compounds from semi-solid or solid foods (Odake et al., 1998; Poinot et al., 2009; van Ruth \& Roozen, 2000; van Ruth et al., 1995). Model mouth systems that mimic mastication were created to 
study flavor release from red bell peppers (van Ruth \& Roozen, 2000; van Ruth et al., 1995). Results from mentioned studies show that that during intra-oral processing, mastication and salivary volume increase affect aroma release in opposite ways, making it difficult to predict in vivo aroma release for solid foods.

So far, the development of artificial mouths and chewing machines, as well as the knowledge of the fundamental physics of mass transfer have provided useful data to help in the understanding of the interactions between flavor compounds and other components of the food. However, the prediction of the behavior of flavor compounds in food systems remains limited (Piggott, 2000).

Many mathematical models have been developed to help us increase our understanding of flavor release during food consumption. When considering a liquid or semi-liquid food, a change in composition of the bolus and a decrease in viscosity have to be considered due to the dilution effect. Recent models have succeeded in modeling flavor release from these liquid boluses, including physiological parameters such as breathing, swallowing and salivary flow rates (Doyennette, de Loubens, Déléris, Souchon, \& Tréléa, 2011; Normand, Avison, \& Parker, 2004; Tréléa et al., 2008). However, when considering a solid matrix, modeling requires detailed knowledge of the mastication process and product fragmentation, which is difficult to obtain experimentally. Existing mechanistic models for solid foods have focused on chewing gums or candies. De Roos and Wolswinkel (de Roos \& Wolswinkel, 1994) developed a model to study the release of aroma compound from a chewing gum. The mastication process was considered as a series of successive extractions of the gum phase and computed to optimize the chewing gum flavoring. However, this model was limited by the fact that the mastication process for a chewing gum is not representative of the one applied for other solid foods and by the fact that the model does not take individual variations such as salivary flow rates and respiratory frequencies into account. Other authors (Hills \& Harrison, 1995; Wright \& Hills, 2003) attempted to build more complex models with candies. To mimic brittle food consumption, they included mastication patterns based on power law or on probabilistic model, respectively, but their approaches are not comparable to real in vivo mastication data. Moreover, their models did not take 
simultaneous fragmentation and dissolution of the product into saliva into account. The changing composition of the bolus over time is a critical phenomenon that leads to changes in physico-chemical properties of aroma compounds and therefore affects their release during the gaseous phase. Understanding the evolution dynamics of those physico-chemical properties during the mixing of the product with saliva is thus of great importance for building more robust models to predict flavor release.

Within this context, the present study aims at exploring the evolution of the air/bolus partition coefficient and of the mass transfer coefficient for two aroma compounds during bolus formation to better understand phenomena involved in flavor release during food consumption. A combined experimental and modeling approach was applied in this work.

\section{$\underline{2 \text { Materials and methods }}$}

\subsection{Cheeses}

Four industrial cheese products (melt-cheese technology) with different compositions and textures (two fat levels and two firmness levels) were designed for this study. Textural properties were characterized by the critical strain and the stress at breakdown as described by Yven et al. (C. Yven et al., 2010). Those rheological parameters were extracted from trials performed at $20^{\circ} \mathrm{C}$ with a rotational viscosimeter Thermofisher - VT550 equipped with a vane geometry FL1000. Data related to cheese characteristics are summarized in Table 1. High-fat cheeses presented lower critical strain at breakdown than low-fat cheeses; and firm cheeses presented a high breakdown stress.

\subsection{Aroma compounds}

Ethyl propanoate and 2-nonanone (Aldrich, Germany) were used and chosen for their difference in physico-chemical properties, particularly in terms of volatility (air/water partition coefficient) and 
hydrophobicity ( $\log$ P) (see Table 2). They are also commonly used in food flavoring, or naturally present, especially in cheeses (Wolf, Perotti, Bernal, \& Zalazar, 2010). Cheeses were flavored with $25.0 \pm 5.0 \mathrm{ppm}(\mathrm{w} / \mathrm{w})$ of ethyl propanoate and $6.3 \pm 1.5 \mathrm{ppm}(\mathrm{w} / \mathrm{w})$ of 2-nonanone. The final concentration of aroma compounds within products was controlled during and after product manufacturing by gas chromatography after an extraction step (Likens Nickerson method).

\subsection{Artificial saliva composition}

Our experimental design did not allow us to use real saliva for in vitro measurements due to the difficulty to collect and manipulate real saliva without altering its composition or its properties (necessity to interrupt enzymatic reactions after specific times, use of chemical/thermal treatment to limit microbiological developments, etc.). Artificial saliva was therefore used for this study. Our principal concern was to select the main ingredients present in real saliva that could have an impact on flavor release and to maintain proportions between constituents that were close to those of real saliva.

The artificial saliva used consisted of three components: water, mucin (for its effect on saliva viscosity and its possible interaction with aroma compounds (van Ruth et al., 2001)) and salt (for its effect on the conformational state of mucin (Friel \& Taylor, 2001)). Only $\mathrm{NaCl}$ was selected for the sake of simplicity, but the global conductivity of our artificial saliva was corrected to be equal to that of real saliva (Drago et al., 2011). The composition of the artificial saliva was: $0.185 \mathrm{~g}$ of $\mathrm{NaCl}$ (GRP RECTAPUR, VWR INTERNATIONAL), $0.216 \mathrm{~g}$ of mucin (from porcine stomach type II, SIGMAALDRICH) and $99.599 \mathrm{~g}$ of water (Milli Q). The solution was stirred for 30 minutes at ambient temperature to allow complete dissolution of mucin, and $\mathrm{pH}$ was adjusted to 7 with $35 \% \mathrm{NaOH}$ (VWR, PROLABO). The artificial saliva was prepared every day and stored at $4^{\circ} \mathrm{C}$ in-between experimental use.

\subsection{Model bolus formation protocol}


The evolution of the bolus was investigated by changing the saliva/cheese ratio. Five ratios were chosen in order to cover the range of dilutions that occur when food is consumed: $100 \%$ of product, $10 \%$ of saliva $+90 \%$ of product (dilution close to the one at the beginning of consumption), $50 \%$ of saliva $+50 \%$ of product (intermediate dilution, close to in vivo composition of cheese bolus found in previous studies (Drago et al., 2011)), $90 \%$ of saliva $+10 \%$ of product (dilution close to the one in the pharynx), and $100 \%$ of saliva (for that ratio, saliva was flavored with a mixture of propylene glycol, ethyl propanoate and 2-nonanone in order to have $25 \mathrm{ppm}(\mathrm{w} / \mathrm{w})$ of each aroma compound in the flavored saliva).

A quantity of $70 \mathrm{~g}$ of bolus (product + saliva) was prepared for each ratio, and the required amount of cheese was determined each time. Pieces of cheeses were cut with a cylindrical punch (diameter: 24 $\mathrm{mm}$ ) and adjusted to a 6-g weight each. They were then placed in a bowl for 30 minutes to allow temperature equilibrium with room temperature. Depending on the saliva/cheese ratio targeted, the required quantity of saliva was added. In order to simulate chewing, the pieces of cheese were mashed in saliva with a "sawtooth" pestle for a specific length of time. Tarrega et al. (Tarrega, Yven, Semon, $\&$ Salles, 2008) showed that hard and low-fat cheeses required longer chewing time to be eaten than soft and high-fat cheeses. Based on critical strain at breakdown (related to the fat level of the cheese) and on eating times observed on similar food products (de Loubens et al., 2011), specific chewing times were chosen as follows: 30 seconds/piece for a low-fat cheese, and 15 seconds/piece for a highfat cheese.

\subsection{Determination of the air/bolus partition coefficients of aroma compounds}

The air/bolus partition coefficient of aroma compound $K_{A B}$ was measured with the Phase Ratio Variation (PRV) method using headspace gas chromatography (Ettre, Welter, \& Kolb, 1993). A known amount of bolus $(50 \mathrm{mg}, 200 \mathrm{mg}, 500 \mathrm{mg}$ or $2000 \mathrm{mg})$ was placed in vials $\left(22.4 \mathrm{~cm}^{3}\right.$, Chromacol, France) and incubated at $35^{\circ} \mathrm{C}$ for 2.5 hours. This length of time was selected after some preliminary experiments (measurements every 30 minutes from 0 to 5 hours) to ensure the 
establishment of the thermodynamic equilibrium. The temperature was selected to be close to inmouth conditions.

After this equilibration time, $2 \mathrm{~cm}^{3}$ of the headspace above the bolus was sampled and injected with an automatic HS CombiPal sampler (CTC Analytics, Switzerland) into a gas chromatograph HP (GC-FID HP6890, Germany) equipped with an HP-INNOWax polyethylene glycol semi-capillary column (30 m x $0.53 \mathrm{~mm}$, with a $1 \mu \mathrm{m}$-thick film) (J\&W Scientific) and a flame ionization detector. The temperatures of the gas chromatograph injector and detector (GC-FID HP6890, Germany) were both set at $250^{\circ} \mathrm{C}$. The oven program was $12 \mathrm{~min}$ long, starting at $40^{\circ} \mathrm{C}$ for $5^{\circ} \mathrm{C} / \mathrm{min}$ up to $60^{\circ} \mathrm{C}$, then for $10^{\circ} \mathrm{C} / \mathrm{min}$ up to $120^{\circ} \mathrm{C}$, and $2 \mathrm{~min}$ at $120^{\circ} \mathrm{C}$. The carrier gas was helium (flow rate: $8.4 \mathrm{~cm}^{3} / \mathrm{min}$, corresponding to a $57 \mathrm{~cm} / \mathrm{s}$ average velocity at $50^{\circ} \mathrm{C}$ ). Peak areas were measured using HewlettPackard Chemstation integration software. A non-linear regression was performed on the data set as described in Atlan et al. (Atlan, Trelea, Saint-Eve, Souchon, \& Latrille, 2006) using MatLab®. Three replicates were performed for each bolus tested.

\subsection{Determination of mass transfer coefficients of aroma compounds in the}

\section{bolus}

The determination of the mass transfer coefficients in the bolus $k_{B}$ was done by fitting a release model to experimental data. As previously done by Marin et al. (Marin, Baek, \& Taylor, 1999) or Lauverjat et al. (Lauverjat, de Loubens, Déléris, Tréléa, \& Souchon, 2009), the mechanistic model used here describes the main mass transfer phenomena occurring in the flask, and leads to a set of differential equations. The main assumptions were local thermodynamic equilibrium at the interface, mass flux conservation through the interfaces at all times and mass balances for each phase. Appendix A provides details about the system of equations.

Five grams of bolus were poured into $134.8-\mathrm{cm}^{3}$ vials (three replicates/bolus). The samples were left for $2.5 \mathrm{~h}$ at $35^{\circ} \mathrm{C}$ to let the thermodynamic equilibrium establish itself. The headspace was then 
stripped by a gaseous flow at a controlled rate of $1.45 \mathrm{~cm}^{3} / \mathrm{s}$ (Brooks Digital Mass Flow Meter, Brooks Instrument 5860s). The evolution of headspace concentration over time was measured with a Proton Transfer Reaction Mass Spectrometer (PTR-MS, Ionicon, Innsbruck, Austria) for 40 minutes. The experiment time had to be longer than four times the characteristic time of the headspace stripping $\mathrm{V} / \mathrm{Q}$, where $\mathrm{V}$ is the volume of the headspace and $\mathrm{Q}$ the stripping airflow rate, to be sure that headspace concentration was mainly due to the transfer from the product to the air.

The PTR-MS inlet was connected to samples via a $1 / 16^{\prime \prime}$ PEEK tube maintained at $60^{\circ} \mathrm{C}$. The PTRMS instrument drift tube was thermally controlled $\left(\right.$ Tdrift $\left.=60^{\circ} \mathrm{C}\right)$ and operated at Pdrift $=200 \mathrm{~Pa}$ with a voltage set of Udrift $=600 \mathrm{~V}$. Measurements were performed with the multiple ion detection mode on specific masses/charge with a dwell time of $50 \mathrm{~ms}$ per mass/charge. Ethyl propanoate was monitored on $\mathrm{m} / \mathrm{z} 103$ (protonated molecular ion) and 2-nonanone on $\mathrm{m} / \mathrm{z} 143$ from preliminary fragmentation experiments. In addition, masses/charge $\mathrm{m} / \mathrm{z} 21$ (signal for $\mathrm{H}_{3}{ }^{18} \mathrm{O}^{+}$) and $\mathrm{m} / \mathrm{z} 37$ (signal for water clusters $\mathrm{H}_{2} \mathrm{O}-\mathrm{H}_{3} \mathrm{O}^{+}$) were monitored with a dwell time of $100 \mathrm{~ms}$ to check the instrument performances and cluster ion formation.

Intensity of ion $\mathrm{m} / \mathrm{z} 21$ was $(3.81 \pm 0.71) \times 10^{4} \mathrm{cps}$, and the variation of the ratio of intensities $\mathrm{m} / \mathrm{z} 21$ and $\mathrm{m} / \mathrm{z} 37$ were lower than $5 \%$ and $6 \%$, respectively. These differences were considered sufficiently small to ensure accurate PTR-MS measurements. Two to five replicates were performed for each bolus tested. Signal intensities were normalized as follows before the fitting step with MatLab ${ }^{\circledR}$ software, as previously done by Sinah et al. (Sinha, Custer, Kluepfel, \& Williams, 2009):

$$
\mathrm{I}_{\text {norm }}=\mathrm{I}_{\text {signal }} \times 10^{6} \times 2 \times \mathrm{T}_{\text {drift }} /\left[\left(\mathrm{I}_{21}+\mathrm{I}_{37}\right) \times \mathrm{P}_{\text {drift }} \times 298.15\right]
$$

with $\mathrm{T}_{\text {drift }}$ in ${ }^{\circ} \mathrm{C}$ and $\mathrm{P}_{\text {drift }}$ in $\mathrm{Pa}$.

Fitting the release model to experimental data allowed the determination of the mass transfer coefficients of the aroma compound in the boluses. 


\subsection{Statistical analysis}

Statistical tests were performed on the data set. A normality test (performed with the univariate procedure using SAS/Stat ${ }^{\circledR}$ software) showed that the data were not normally distributed. KruskalWallis tests were therefore performed (nonparametric test for independent samples). A utility tool for Excel available at www.Anastats.fr and developed by P. Georgina \& M. Gouet was used (Georgina \& Gouet, 2000). Rankings of samples were then obtained by the non-parametric test of multiple comparisons (Dunn method, level of significance set at 5\%) (Dunn, 1964). For the correlation test, the Spearman test was performed, with a level of significance set at 5\% (a utility tool for Excel also available at www.Anastats.fr and developed by P. Georgina \& M. Gouet was used (Georgina \& Gouet, 2000)).

\section{$\underline{3 \text { Results and discussion }}$}

The evolution of the air/bolus partition coefficient and of the mass transfer coefficient of aroma compounds with saliva dilution and product composition is presented in this section. The experimental approach was first conducted on ethyl propanoate and validated on 2-nonanone, each of which presents different physico-chemical properties.

\subsection{Air/bolus partition coefficients for ethyl propanoate}

The air/bolus partition coefficients determined for ethyl propanoate are presented in Fig. 1. Air/bolus partition coefficients ranged between $0.55 \times 10^{-2}$ (case of the cheese Fh diluted to $50 \%$ ) and $2.82 \times 10^{-2}$ (case of flavored saliva). The values for flavored saliva were on the same order of magnitude as the ones available in the literature for similar aroma compounds (ethyl acetate and ethyl butanoate), even if the temperatures studied (from $25^{\circ} \mathrm{C}$ to $37^{\circ} \mathrm{C}$ ), the methods used (PRV or static headspace analysis) and the type of solutions (water, water + salts or water + salts + proteins) were different (Atlan et al., 2006; Savary, Guichard, Doublier, \& Cayot, 2006; van Ruth et al., 2001). 
Results highlighted that boluses made from the Fh cheese were slightly different than those from the other cheese boluses (the values of the air/bolus partition coefficient for this cheese were consistently lower than for the other cheeses). However, we distinguished a general trend for all of the cheeses: the air/bolus partition coefficient decreases with the decrease of the cheese/saliva ratio ( the greater the amount of saliva incorporated into the bolus, the higher the air/bolus partition coefficient). Various hypotheses can be proposed to explain this general trend. In the case of pure cheese, there are physicochemical interactions between cheese components and ethyl propanoate, as well as a structural effect, resulting in higher retention of this aroma compound (air/bolus partition coefficients of $0.91 \times 10^{-2}$ on average for pure cheese vs. $2.82 \times 10^{-2}$ for flavored saliva). These results are in agreement with the work of (van Ruth et al., 2001), who observed that high molecular and hydrophobic aroma compounds such as ethyl acetate and ethyl butyrate had highest retention in oil than in water or in saliva. Those findings comfort that saliva dilution plays an important role in aroma release

With the addition of saliva, we can assume that: (a) there are fewer component/volatile molecule interactions; (b) the fat is more diluted in the global bolus, both of these phenomena leading to a greater release of ethyl propanoate or (c) mucin/volatile molecule interactions, as already observed in literature (Genovese et al., 2009; van Ruth \& Roozen, 2000; van Ruth et al., 1996). This last hypothesis suggests that the release of aroma compound decreases with addition of artificial saliva. However, this was not observed in our study, which means that mucin/volatile molecule interactions are probably minor compare to phenomena (a) and (b). This is reinforced by the study of (Poinot et al., 2009), who did not observe a mucin effect by mixing artificial saliva with bread in their model mouth. They hypothesized that it was probably because of the complexity of the food system. In addition, these mucin/volatile interactions might be counteracted by mechanical forces, similarly to what is observed by (van Ruth et al., 1995) in some of their mouth model systems.

The dilution effect of saliva on air/bolus partition coefficient for ethyl propanoate was statistically tested for each cheese. Two separate groups could be identified: cheeses FFl, Sl and Sh vs. cheese Fh (firm with high fat content). Results are presented in Table 3. 
For cheeses FFl (very firm and low fat content), Sl (soft and low fat content) and Sh (soft and high fat content), the greater the dilution, the greater the air/bolus partition coefficient. Two distinct groups are formed: boluses rich in saliva (pure saliva and dilution 90s-10p) are statistically different from poorly diluted boluses (dilution 10s-90p and pure product). Air/bolus partition coefficients vary up to a factor 3 between poorly and highly diluted boluses;

For cheese Fh (firm with high fat content), the trend is less clear: globally, boluses rich in saliva (pure saliva and dilution 90s-10p) are different from intermediate and poorly diluted boluses. However, only the value of the air/bolus partition coefficient for dilution 50s-50p is significantly different from that of flavored saliva. The mechanical properties of this cheese (low critical strain at breakdown and high breakdown stress, table 1) could account for this specific behavior.

During eating, the dynamics of oral processing of a food lead to an increase in the dilution rate of the food bolus by saliva in mouth. The following equations were established to describe the evolution of the air/bolus partition coefficient $K_{A B}$ for ethyl propanoate as a function of the cheese/saliva ratio $r_{c s}$. To do this, non-linear regressions were performed on experimental data for each group:

- $K_{A B}=2.18 \times 10^{-2} \times r_{c s}{ }^{2}-3.82 \times 10^{-2} \times r_{c s}+2.63 \times 10^{-2}\left(\mathrm{R}^{2}=0.95\right)$ for cheeses FFl, Sl and Sh

$\cdot K_{A B}=2.73 \times 10^{-3} \times r_{c s}{ }^{2}-2.15 \times 10^{-2} \times r_{c s}+4.72 \times 10^{-2}\left(\mathrm{R}^{2}=0.98\right)$ for the cheese $\mathrm{Fh}$

with $r_{c s}=0$ for the flavored saliva and $r_{c s}=1$ for the pure cheese.

These equations are useful tools for predicting the volatility of aroma compounds during in-mouth processing but require many experimental data to be established. For predicting these values with less experimentation, we propose to adapt Buttery's equation from Buttery et al. (Buttery, Guadagni, \& Ling, 1973). The author proposed a simple calculation method for describing the overall distribution of volatile molecules between air and an emulsion phase, regardless of fat content, knowing only the partition properties of each biphasic system, between fat and air and between water and air. This equation is based on mass balance at thermodynamic equilibrium and on the assumption that the interface between the phases does not affect the value of the partition coefficient in a multiphase 
system. This hypothesis means that the structure effect of the emulsion is negligible in comparison to the composition effect (fat and water content), and can be written as follows (see Equation 1):

$$
K_{A E}=1 /\left(F_{W} / K_{A W}+F_{O} / K_{A O}\right)
$$

where $K_{A E}$ is the partition coefficient between the air and the emulsion, $K_{A W}$ and $K_{A O}$ are the partition coefficients between the air and the water phase and the air and the oil phase, respectively, and $F_{W}$ and $F_{O}$ are the volume fractions of the water phase and oil phase, respectively, in emulsion. Validation of experimental results have been frequently performed with this equation on emulsion studies (Déléris, Zouid, Souchon, \& Tréléa, 2009; Guyot et al., 1996; van Ruth et al., 2001). To predict the impact of cheese bolus structure on the air/bolus partition coefficient, we propose using an adapted Buttery equation by replacing the emulsion phase with a multiphase matrix (i.e., our boluses made of a product phase and of a saliva phase). Knowing the physico-chemical properties of each phase, we can then calculate the partition coefficient between the air and the mixtures (boluses) with the following equation:

$$
K_{A B}=1 /\left(F_{S} / K_{A S}+F_{C} / K_{A C}\right)
$$

where $K_{A B}$ is the partition coefficient between the air and the bolus, $K_{A S}$ and $K_{A C}$ are the partition coefficients between the air and the saliva and air and the cheese, respectively, and $F_{S}$ and $F_{C}$ are the volume fraction of saliva and cheese in the bolus.

We used experimental values of coefficients $\mathrm{K}_{\mathrm{AS}}$ and $\mathrm{K}_{\mathrm{AC}}$ for ethyl propanoate to calculate the theoretical air/bolus partition coefficient for each bolus dilution.

Figure 2 compares experimental and predicted values for air/bolus partition coefficients for ethyl propanoate using the adapted Buttery equation (all cheeses and all boluses). It shows a strong correlation between our experimental values and the ones predicted using Buttery's equation (correlation coefficient of 0.86 , statistically significant at the $5 \%$ level according to the Spearman test) for all bolus dilutions and all cheeses. This good overall correlation validates the hypothesis that the partition of ethyl propanoate is determined more by the composition than the structure of the cheese 
product. However, in the specific case of cheese Fh, it seems that there is a structure effect that might not be negligible in partition behavior (correlation coefficient of 0.94 without cheese Fh).

\subsection{Mass transfer coefficients of ethyl propanoate in the bolus}

Results of mass transfer coefficients of ethyl propanoate in the bolus are presented in Figs. 3 and 4. Mass transfer coefficients of ethyl propanoate in the bolus $\left(k_{B}\right)$ ranged from $1.84 \times 10^{-7} \mathrm{~m} / \mathrm{s}$ (cheese $\mathrm{Fh}$ with a $50 \%$ dilution) to $2.44 \times 10^{-6} \mathrm{~m} / \mathrm{s}$ (pure cheese $\mathrm{Fh}$ ).

No common trend for dilution effect can be distinguished for all of the cheeses. However, two groups with similar behavior could be observed in terms of the firmness level of the cheeses. We therefore performed Kruskal-Wallis tests on each of these groups: cheeses FFl and Fh vs. cheeses Sl and Sh. Rankings are presented in Table 4.

We observed that there was a significant effect of dilution rate for each group at the $5 \%$ level. Firm matrices (FFl and Fh) have a parabolic shape evolution of their mass transfer coefficient with the addition of saliva in the bolus, with a minimum for the $50 \%$ dilution by saliva (see Fig. 3 ).

Soft matrices (Sl and Sh) kinetics have three groups of products (see Fig. 4): (i) intermediate or poor in saliva boluses (pure product, $10 \%$ or $50 \%$ dilution) have similar and low values of mass transfer coefficient, (ii) highly diluted boluses (90s-10p) have an intermediate value, (iii) pure saliva has the highest mass transfer coefficient value.

The following equations were established to describe the evolution of the mass transfer coefficient $\left(k_{B}\right)$ of ethyl propanoate in the bolus as a function of the cheese/saliva ratio $r_{c s}$. To do this, non-linear regressions were performed on experimental data for each group based on textural properties:

$\cdot k_{B}=7.85 \times 10^{-6} \times r_{c s}^{2}-7.71 \times 10^{-6} \times r_{c s}+2.05 \times 10^{-6}\left(\mathrm{R}^{2}=0.83\right)$ for the firm cheeses (FFl and Fh)

$\cdot k_{B}=3.19 \times 10^{-6} \times r_{c s}{ }^{2}-4.42 \times 10^{-6} \times r_{c s}+1.77 \times 10^{-6}\left(\mathrm{R}^{2}=0.85\right)$ for the soft cheeses (S1 and Sh) 
where $r_{c s}=0$ for the flavored saliva and $r_{c s}=1$ for the pure cheese.

The difference in the evolution of the mass transfer coefficient of ethyl propanoate in the bolus according to cheese firmness could be explained by the two following assumptions.

First, during the formation of the bolus with hard cheeses, a heterogeneous mixture made of small pieces of cheese bathed in saliva is formed. In that case: (i) for pure cheese boluses, we assumed that the fracturing of flavored watery pockets present in the matrix could promote a rapid transition of ethyl propanoate to the air phase;(ii) for highly diluted boluses (90s-10p), we hypothesized that the small pieces of cheese in the bolus are exhausted in aroma compounds (the measurement of the mass transfer coefficient is therefore similar to the one in flavored saliva);(iii) for intermediate dilutions (50s-50p and 10s-90p), we can assume that a combination of many factors that must be identified have to be considered, explaining a moderate transfer of ethyl propanoate to the air phase.

Second, during the formation of the bolus with soft cheeses, a homogeneous mixture is formed. In this case, the more the food boluses are diluted, the less viscous they are, and the quicker the transfer of ethyl propanoate into the air phase is. Those hypotheses remain speculative and need further confirmation. For example, evaluation of the cheese and food bolus microstructure could be performed, similarly to the work of (Cunha, Dias, \& Viotto, 2010) or (Calligaris, Pieve, Arrighetti, \& Barba, 2010).

The different results show that there is a dilution effect on the air/bolus partition coefficient and both a dilution and a product effect (firmness) on the mass transfer coefficient in the bolus for ethyl propanoate. The physico-chemical properties of the aroma compound depending on the bolus state therefore seem to be important for flavor release. Validation of these results was performed with 2nonanone, which is less volatile and more hydrophobic than ethyl propanoate.

\subsection{Validation with 2-nonanone}


For 2-nonanone, the air/bolus partition coefficient was measured for the saliva and the pure product and Buttery's equation was used to obtain the intermediate air/bolus partition coefficients.

Results are presented in Table 5. The air/saliva partition properties of 2-nonanone were on the same order of magnitude as the ones available in the literature for similar aroma compounds (2-octanone and 2-decanone), even if the determination method used (static headspace analysis) or the type of solution (water, water+salts or water+salts+proteins) were different (van Ruth et al., 2001).

The mass transfer coefficients of 2-nonanone into the bolus were then determined with the same dynamic headspace method as described previously. Due to the high level of fat and the low flavoring of cheeses, experiments were at the limit of the method and of the detection of the PTR-MS apparatus. Therefore, only the low-fat cheeses (FFl and $\mathrm{Sl}$ ) gave usable results. Nevertheless, the trends observed for ethyl propanoate were confirmed (Figs. 5 and 6). The evolution of the mass transfer coefficient of 2-nonanone with the saliva/cheese ratio for the firm cheese FFl showed a parabolic shape. Three groups were obtained from the evolution of the mass transfer coefficient of 2-nonanone with the saliva/cheese ratio for the firm cheese Sl.

This step allowed us to validate the experimental and modeling approach on a more hydrophobic aroma compound than ethyl propanoate. Though, additional measurements with cheeses of intermediate texture and composition or with other aroma compounds could help to confirm those results and to gain insight on the mechanisms that explain the different behaviors observed in this study.

\section{Conclusions}

This study investigated the evolution of physico-chemical properties of boluses made of cheese and saliva at different stages of oral processing. It was observed that regardless of the cheese considered, the air/bolus partition coefficients for ethyl propanoate increase with the amount of saliva 
incorporated. For the mass transfer coefficients of ethyl propanoate within the bolus, two different trends were observed, depending on the level of firmness of cheeses.

These results have been validated with a less volatile and more hydrophobic aroma compound (2nonanone) on low-fat cheeses.

These findings show that mastication and mixing with saliva changes the physico-chemical properties of aroma compounds in food boluses. Those properties are key parameters for determining flavor release during food consumption. As a consequence, their evolution during food consumption strongly affects aroma release.

Therefore, in terms of mechanistic modeling of flavor release during consumption of a solid food, those parameters have to be integrated into physical equations to give reliable predictions. Empirical regressions depending on saliva dilution were performed in this study to predict the physico-chemical properties of the aroma compound during bolus formation.

For the investigation of other complex foods and aroma compounds, the present experimental design could be difficult to perform. In that case, we would recommend using the adapted Buttery equation, which led to good predictions of air/bolus partition coefficients during the dynamic formation of the bolus. Considerable time can by saved by using this simple equation.

For the evolution of the mass transfer coefficient in the bolus with saliva dilution, we found that the structure of the products plays a key role. The trends observed for our specific foods and aroma compounds could not be easily predictable. Therefore, this type of determination is of great importance for the modeling approach and should be performed for each type of food investigated.

This study allowed us to better understand and predict the dynamics of the evolution of aroma compound transfer properties in solid food products during simulated oral processing. These results are useful tools that can be integrated into mechanistic models for in vivo flavor release prediction during the eating of solid foods. 


\section{Acknowledgements}

The authors gratefully acknowledge the French National Research Agency (ANR) project "SensInMouth" for financial support.

The authors gratefully acknowledge David Forest for technical assistance.

The authors gratefully acknowledge Gail Wagman for revising the English version of the manuscript. 


\section{$\underline{\text { References }}$}

Atlan, S., Trelea, I. C., Saint-Eve, A., Souchon, I., \& Latrille, E. (2006). Processing gas chromatographic data and confidence interval calculation for partition coefficients determined by the phase ratio variation method. Journal of Chromatography A, 1110 (1-2), 146-155

Buettner, A. (2002a). Influence of Human Saliva on Odorant Concentrations. 2. Aldehydes, Alcohols, 3-Alkyl-2-methoxypyrazines, Methoxyphenols, and 3-Hydroxy-4,5-dimethyl-2(5H)-furanone. Journal of Agricultural and Food Chemistry, 50 (24), 7105-7110

Buettner, A. (2002b). Influence of Human Salivary Enzymes on Odorant Concentration Changes Occurring in Vivo. 1. Esters and Thiols. Journal of Agricultural and Food Chemistry, 50 (11), 3283-3289

Buttery, R. G., Guadagni, D. G., \& Ling, L. C. (1973). Flavor compounds. Volatilities in vegetable oil and oil-water mixtures. Estimation of odor thresholds. Journal of Agricultural and Food Chemistry, 21 (2), 198-201

Calligaris, S., Pieve, S. D., Arrighetti, G., \& Barba, L. (2010). Effect of the structure of monoglyceride-oil-water gels on aroma partition. Food Research International, 43 (3), 671677.

Cunha, M. R., Dias, A. I., \& Viotto, W. H. (2010). Microstructure, texture, colour and sensory evaluation of a spreadable processed cheese analogue made with vegetable fat. Food Research International, 43 (3), 723-729.

de Loubens, C., Panouillé, M., Saint-Eve, A., Déléris, I., Tréléa, I. C., \& Souchon, I. (2011). Mechanistic model of in vitro salt release from model dairy gels based on standardized breakdown test simulating mastication. Journal of Food Engineering, In Press, Corrected Proof

de Roos, K. B., \& Wolswinkel, K. (1994). Non-equilibrium partition model for predicting flavour release in the mouth. In Maarse \& D. G. ven der Heij (Eds.), (pp. 15-32 ): Elsevier Science. 
Déléris, I., Zouid, I., Souchon, I., \& Tréléa, I. C. (2009). Calculation of apparent diffusion coefficients of aroma compounds in dairy emulsions based on fat content and physicochemical properties in each phase. Journal of Food Engineering, 94 (3-4), 205 - 214

Doyennette, M., de Loubens, C., Déléris, I., Souchon, I., \& Tréléa, I. C. (2011). Mechanisms explaining the role of viscosity and post-deglutitive pharyngeal residue on in vivo aroma release: a combined experimental and modeling study. Food Chemistry, 128, 380-390.

Drago, S. R., Panouillé, M., Saint-Eve, A., Neyraud, E., Feron, G., \& Souchon, I. (2011). Relationships between saliva and food bolus properties from model dairy products. Food Hydrocolloids, 25 (4), 659 - 667

Dunn, O. J. (1964). Multiple Comparisons Using Rank Sums. In (Vol. 6 pp. 241-252 ): Technometrics.

Ettre, L., Welter, C., \& Kolb, B. (1993). Determination of gas-liquid partition coefficients by automatic equilibrium headspace-gas chromatography utilizing the phase ratio variation method. Chromatographia, 35 (1), 73-84

Friel, E. N., \& Taylor, A. J. (2001). Effect of Salivary Components on Volatile Partitioning from Solutions. Journal of Agricultural and Food Chemistry, 49 (8), 3898-3905

Genovese, A., Piombino, P., Gambuti, A., \& Moio, L. (2009). Simulation of retronasal aroma of white and red wine in a model mouth system. Investigating the influence of saliva on volatile compound concentrations. Food Chemistry, $114(1), 100$ - 107

Georgina, P., \& Gouet, M. (2000). Statistics with Excel 2000: Eyrolles.

Guyot, C., Bonnafont, C., Lesschaeve, I., Issanchou, S., Voilley, A., \& Spinnler, H. E. (1996). Effect of Fat Content on Odor Intensity of Three Aroma Compounds in Model Emulsions: $\hat{I}^{\prime}-$ Decalactone, Diacetyl, and Butyric Acid. Journal of Agricultural and Food Chemistry, 44 (8), $2341-2348$

Hills, B. P., \& Harrison, M. (1995). Two-film theory of flavour release from solids. International Journal of Food Science and Technology, 30 (4), 425-436 
Lauverjat, C., de Loubens, C., Déléris, I., Tréléa, I. C., \& Souchon, I. (2009). Rapid determination of partition and diffusion properties for salt and aroma compounds in complex food matrices. Journal of Food Engineering, 93 (4), 407-415

Marin, M., Baek, I., \& Taylor, A. J. (1999). Volatile Release from Aqueous Solutions under Dynamic Headspace Dilution Conditions. Journal of Agricultural and Food Chemistry, 47 (11), 47504755.

Normand, V., Avison, S., \& Parker, A. (2004). Modeling the kinetics of flavour release during drinking. Chemical Senses, 29 (3), 235-245

Odake, S., Roozen, J. P., \& Burger, J. J. (1998). Effect of saliva dilution on the release of diacetyl and 2-heptanone from cream style dressings. Nahrung, 42(6) 385-391

Piggott, J. R. (2000). Dynamism in flavour science and sensory methodology. Food Research International, 33 (3-4), 191-197

Poinot, P., Arvisenet, G., Grua-Priol, J., Fillonneau, C., \& Prost, C. (2009). Use of an artificial mouth to study bread aroma. Food Research International, 42 (5-6), 717 - 726

Prinz, J. F., \& Lucas, P. W. (1997). An optimization model for mastication and swallowing in mammals. Proceedings of the Royal Society of London Series B-Biological Sciences, 264 (1389), 1715-1721.

Salles, C., Chagnon, M.-C., Feron, G., Guichard, E., Laboure, H., Morzel, M., Semon, E., Tarrega, A., \& Yven, C. (2011). In-Mouth Mechanisms Leading to Flavor Release and Perception. Critical Reviews in Food Science and Nutrition, 51 (1), 67-90

Savary, G., Guichard, E., Doublier, J. L., \& Cayot, N. (2006). Mixture of aroma compounds: Determination of partition coefficients in complex semi-solid matrices. Food Research International, $39(3), 372-379$

Sinha, V., Custer, T. G., Kluepfel, T., \& Williams, J. (2009). The effect of relative humidity on the detection of pyrrole by PTR-MS for OH reactivity measurements. International Journal of Mass Spectrometry, $282(3), 108$ - 111. 
Tarrega, A., Yven, C., Semon, E., \& Salles, C. (2008). Aroma release and chewing activity during eating different model cheeses. International Dairy Journal, 18 (8), 849-857

Tarrega, A., Yven, C., Sémon, E., \& Salles, C. (2011). In-mouth aroma compound release during cheese consumption: Relationship with food bolus formation. International Dairy Journal, 21 (5), 358-364.

Tréléa, I. C., Atlan, S., Déléris, I., Saint-Eve, A., Marin, M., \& Souchon, I. (2008). Mechanistic mathematical model for in vivo aroma release during eating of semiliquid foods. Chemical Senses, $33(2), 181-192$

van Aken, G. A., Vingerhoeds, M. H., \& de Hoog, E. H. A. (2007). Food colloids under oral conditions. Current Opinion in Colloid $\backslash \&$ Interface Science, 12 (4-5), 251-262

van Der Bilt, A., Engelen, L., Abbink, J., \& Pereira, L. J. (2007). Effects of adding fluids to solid foods on muscle activity and number of chewing cycles. European Journal of Oral Sciences, $115(3), 198-205$

van Ruth, S. M., Grossmann, I., Geary, M., \& Delahunty, C. M. (2001). Interactions between Artificial Saliva and 20 Aroma Compounds in Water and Oil Model Systems. Journal of Agricultural and Food Chemistry, 49 (5), 2409-2413

van Ruth, S. M., \& Roozen, J. P. (2000). Influence of mastication and saliva on aroma release in a model mouth system. Food Chemistry, 71 (3), 339-345

van Ruth, S. M., Roozen, J. P., \& Cozijnsen, J. L. (1995). Changes in flavour release from rehydrated: Diced bell peppers (Capsicum annuum) by artificial saliva components in three mouth model systems. J. Sci. Food Agric., 67 (2), 189-196

van Ruth, S. M., Roozen, J. P., Nahon, D. F., Cozijnsen, J. L., \& Posthumus, M. A. (1996). Flavour release from rehydrated French beans (Phaseolus vulgaris) influenced by composition and volume of artificial saliva. Zeitschrift fur Lebensmitteluntersuchung und-Forschung A, 203 16

Woda, A., Mishellany, A., \& Peyron, M. A. (2006). The regulation of masticatory function and food bolus formation. Journal of Oral Rehabilitation, 33 840-849 
Wolf, I. V., Perotti, M. C., Bernal, S. M., \& Zalazar, C. A. (2010). Study of the chemical composition, proteolysis, lipolysis and volatile compounds profile of commercial Reggianito Argentino cheese: Characterization of Reggianito Argentino cheese. Food Research International, 43 (4), 1204-1211.

Wright, K. M., \& Hills, B. P. (2003). Modelling flavour release from a chewed bolus in the mouth: Part II. The release kinetics. International Journal of Food Science I\& Technology, 38 361368

Yven, C., Culioli, J., \& Mioche, L. (2005). Meat bolus properties in relation with meat texture and chewing context. Meat Science, 70 (2), 365 - 371

Yven, C., Patarin, J., Magnin, A., Labouré, H., Repoux, M., Feron, G., \& Guichard, E. (2010). Consequences of indiviual chewing strategies on bolus rheological properties at the swallowing threshold. International Conference on Food Oral Processing - Physics, Physiology and Psychology of Eating

Leeds (UK) , July 5th-7th, 2010 


\section{$\underline{\text { Figures }}$}

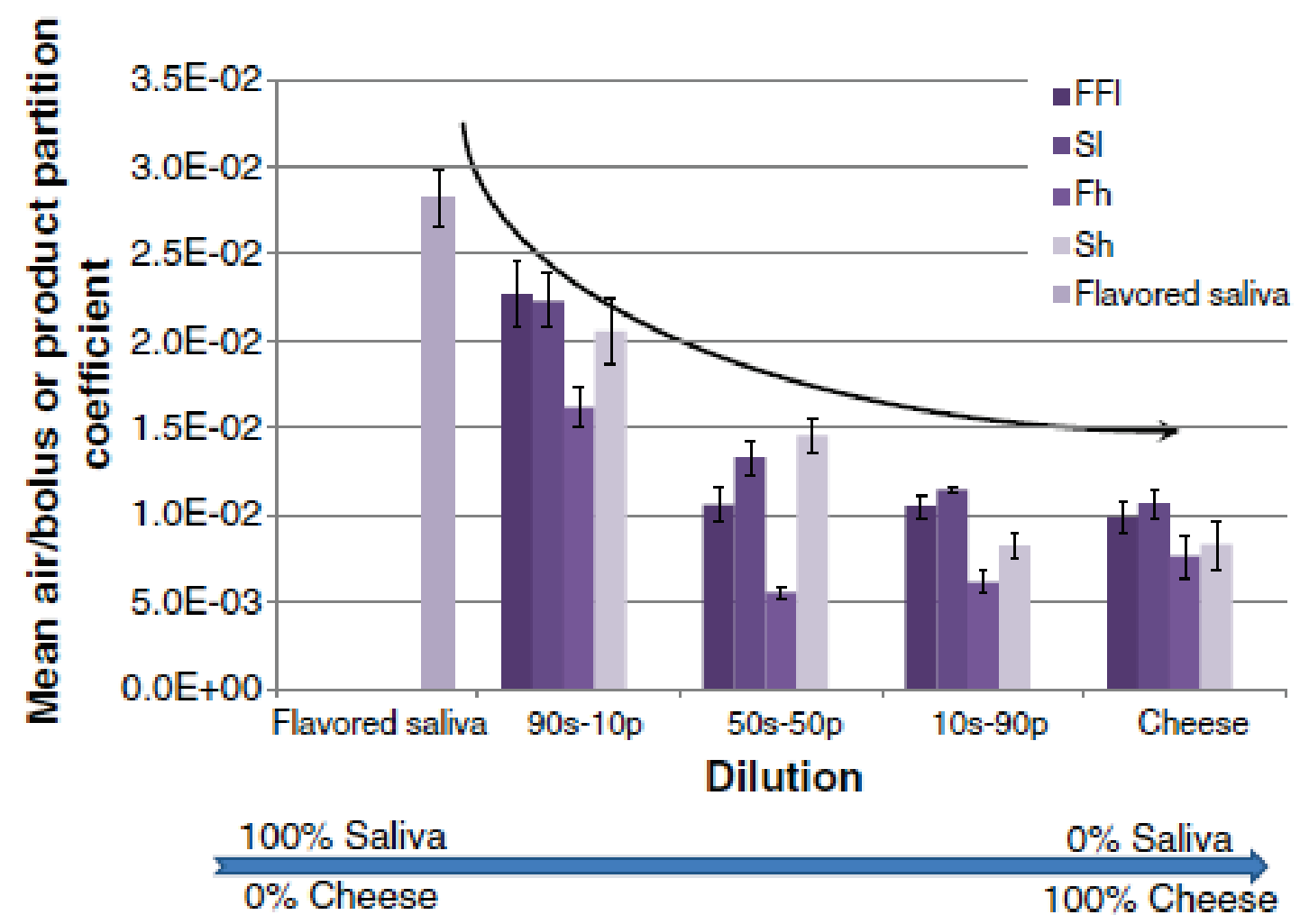

Figure 1. Mean air/bolus partition coefficients and associated standard deviation $\left(K_{A B}\right)$ of ethyl propanoate at $35^{\circ} \mathrm{C}$ as a function of the saliva content of the bolus determined by the PRV method. Values are expressed as dimensionless ratio of mass concentrations. 


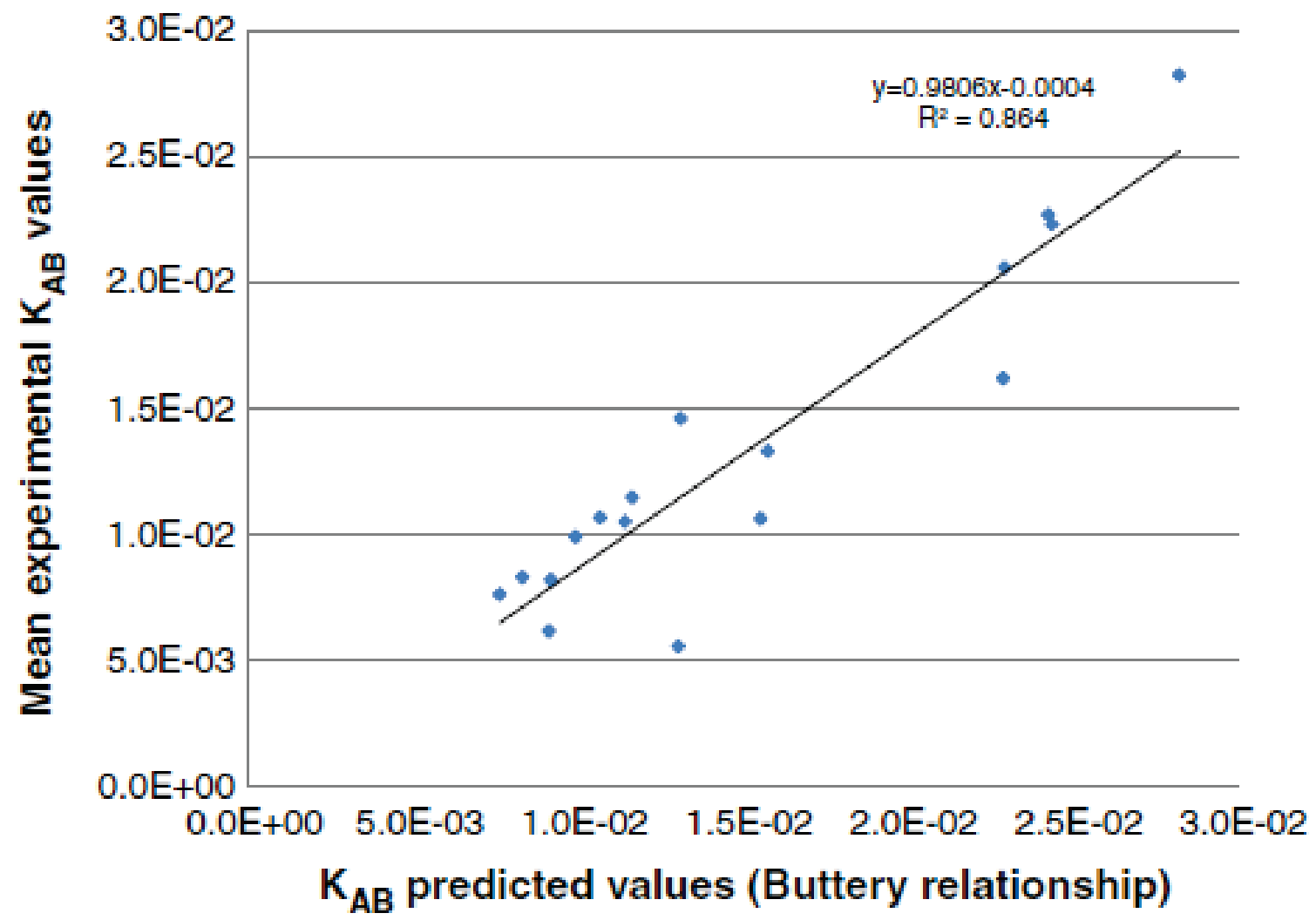

Figure 2. Comparison of mean experimental and predicted values for the air/bolus partition coefficient $\left(K_{A B}\right)$ for ethyl propanoate at $35^{\circ} \mathrm{C}$ using Buttery's equation (all cheeses). 


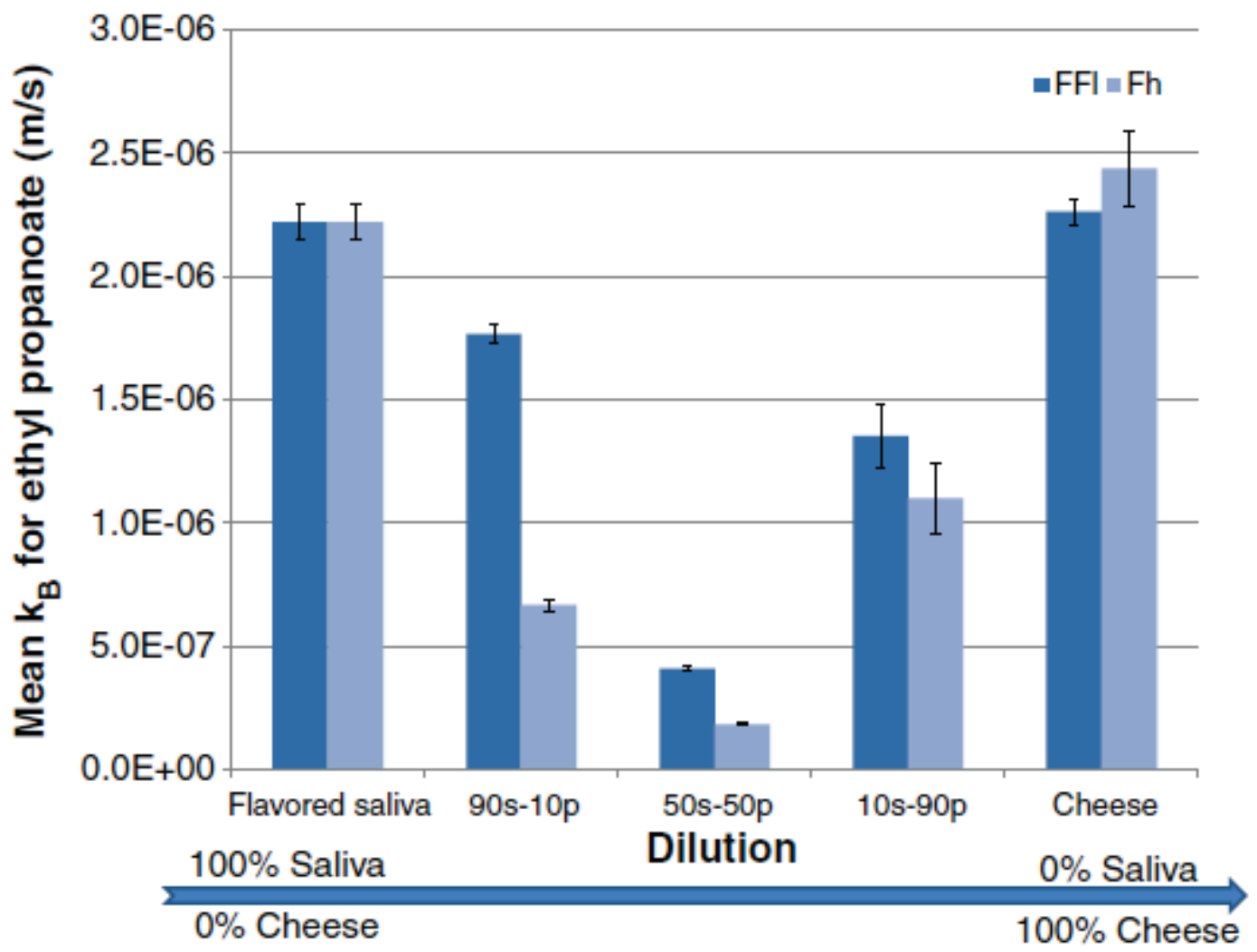

Figure 3. Mean mass transfer coefficient and associated standard deviation of ethyl propanoate in the bolus $\left(k_{B}\right)$ at $35^{\circ} \mathrm{C}$ as a function of saliva dilution: case of firm cheeses $\mathrm{FFl}$ and $\mathrm{Fh}$. 


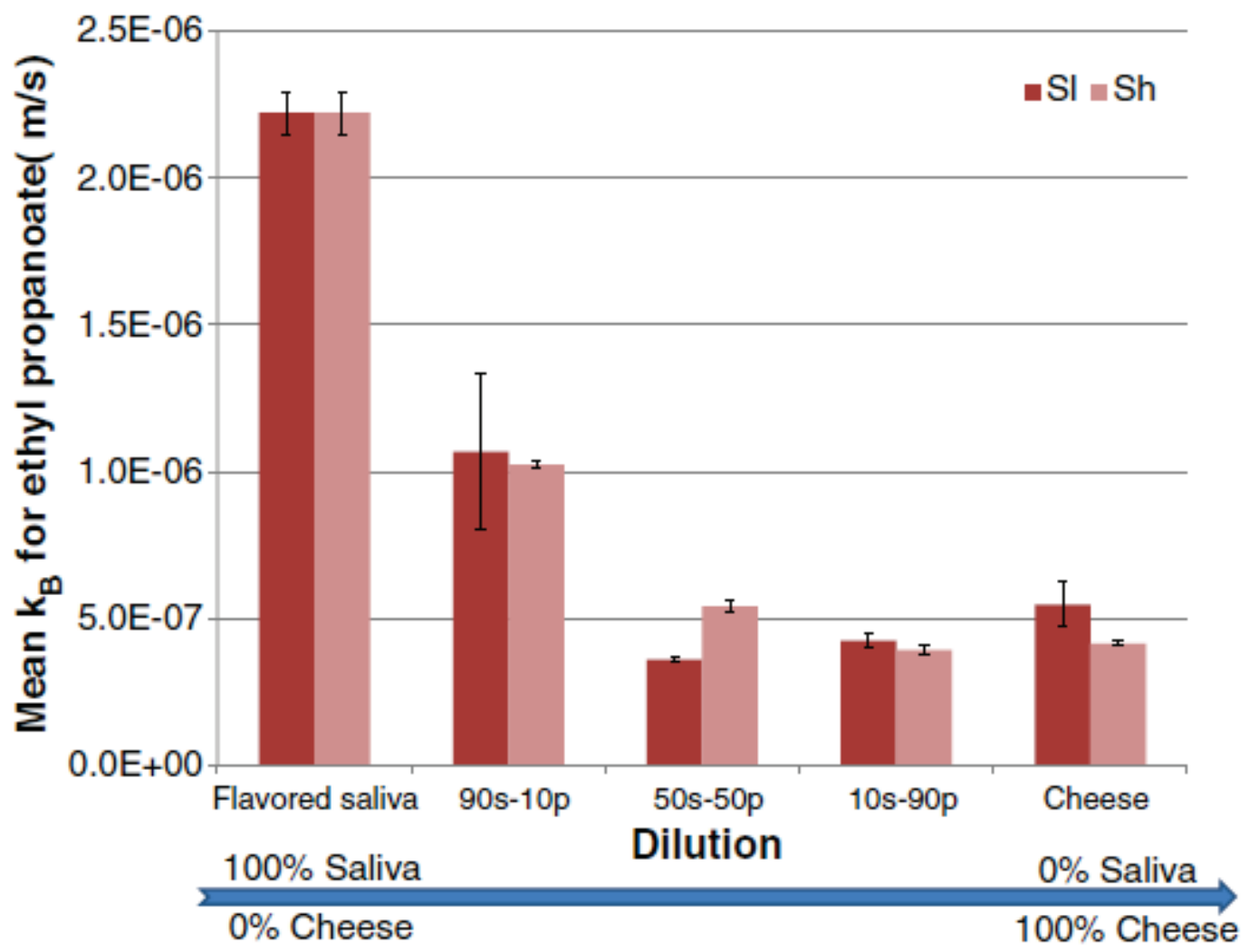

Figure 4. Mean mass transfer coefficient and associated standard deviation of ethyl propanoate in the bolus $\left(k_{B}\right)$ at $35^{\circ} \mathrm{C}$ as a function of saliva dilution: case of soft cheeses $\mathrm{Sl}$ and $\mathrm{Sh}$. 


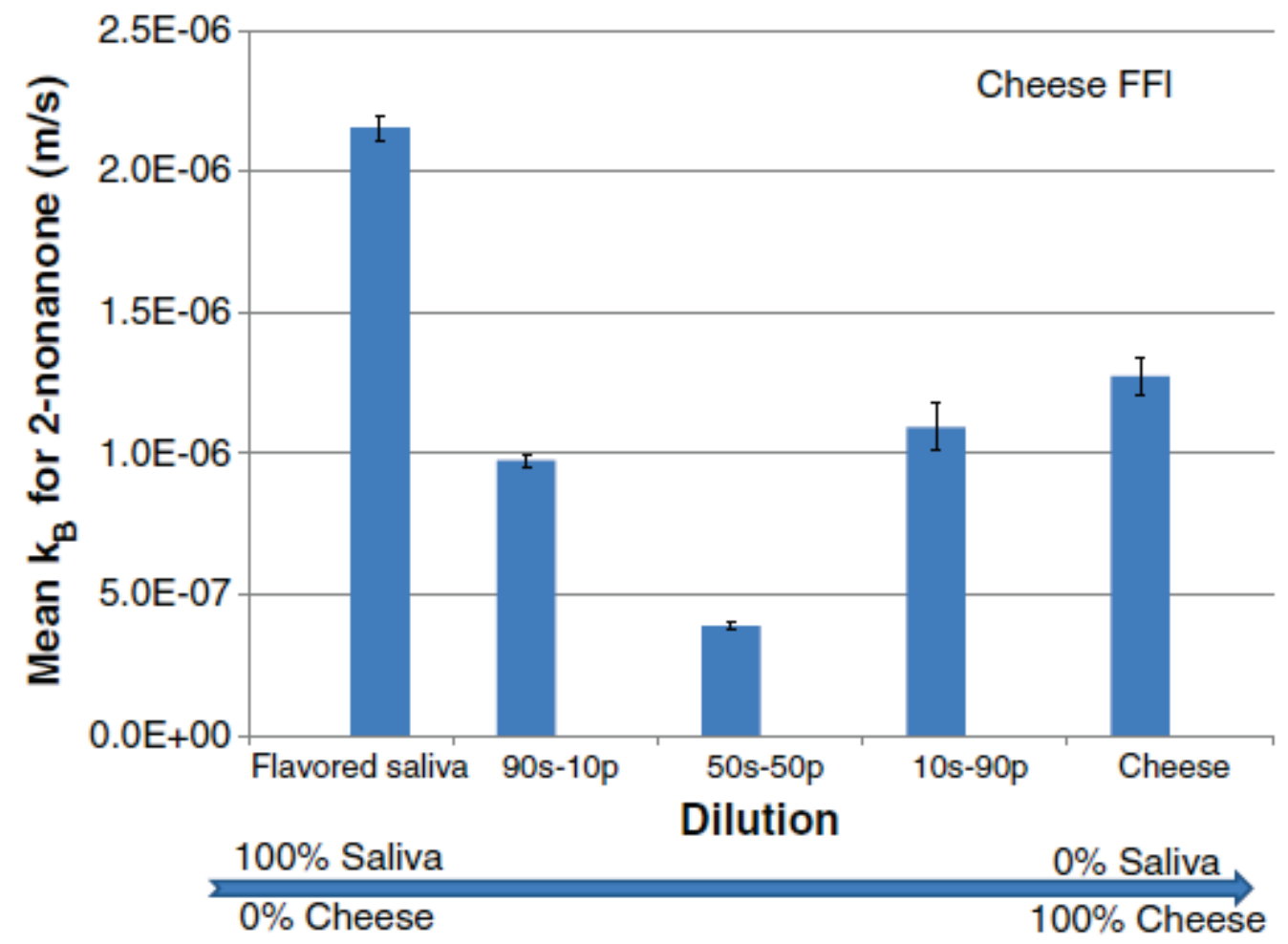

Figure 5. Mean mass transfer coefficient and associated standard deviation of 2-nonanone in the bolus $\left(k_{B}\right)$ at $35^{\circ} \mathrm{C}$ as a function of saliva dilution: case of cheese FFl. For pure saliva, 5 replicates were performed, for dilution 50s-50p, 2 replicates were performed, for dilutions 90s-10p, 10s-90p and pure cheese, 3 replicates were performed. 


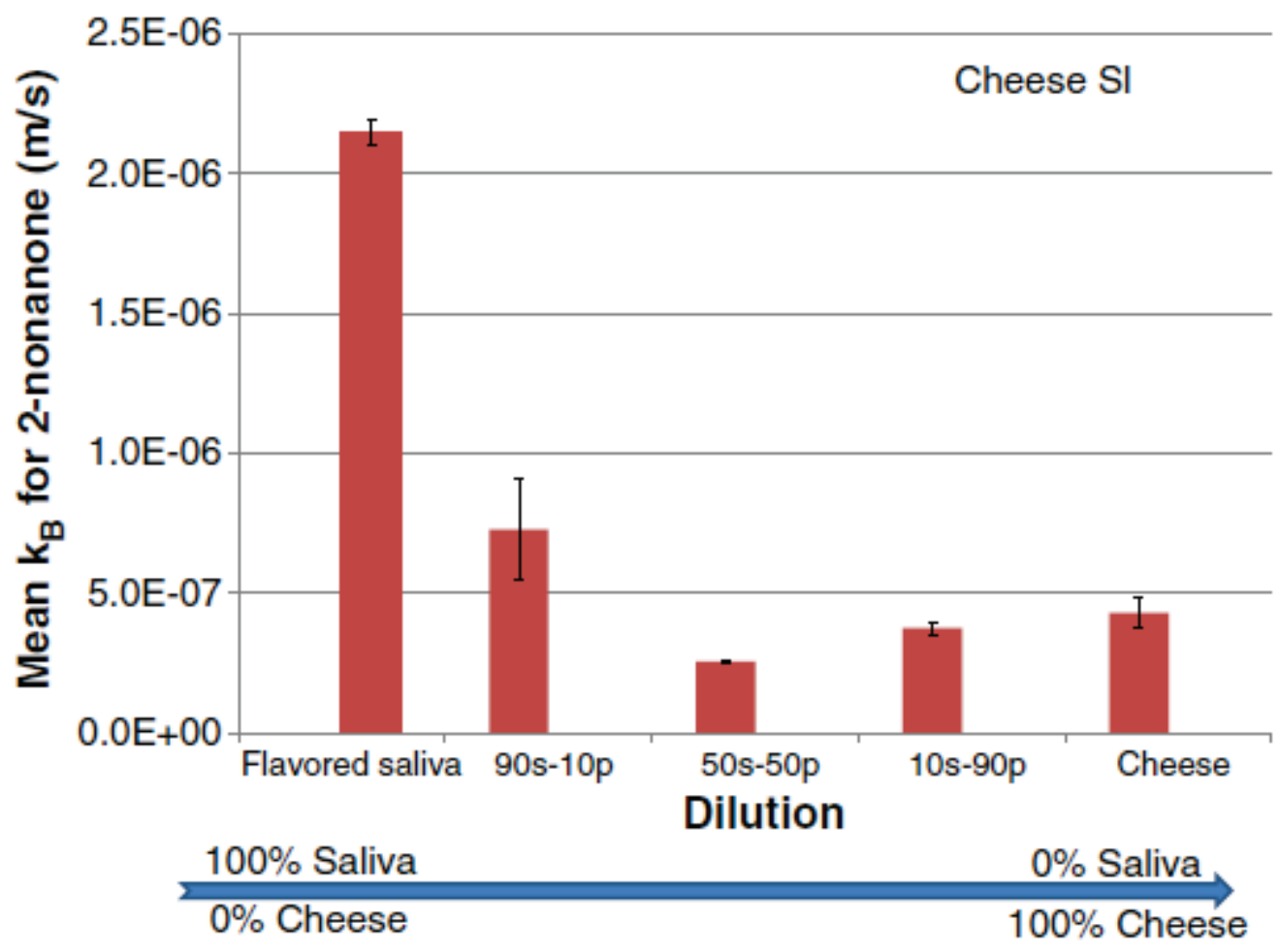

Figure 6. Mean mass transfer coefficient and associated standard deviation of 2-nonanone in the bolus $\left(k_{B}\right)$ at $35^{\circ} \mathrm{C}$ as a function of saliva dilution: case of cheese Sl. For pure saliva, 5 replicates were performed, for dilution $90 \mathrm{~s}-10 \mathrm{p}, 2$ replicates were performed, for dilutions $10 \mathrm{~s}-90 \mathrm{p}, 50 \mathrm{~s}-50 \mathrm{p}$ and pure cheese, 3 replicates were performed. 


\section{Tables}

Table 1. Sample characteristics of the four types of cheese products

\begin{tabular}{|c|c|c|c|c|c|c|c|c|c|c|c|}
\hline Code & Description & $\begin{array}{l}\text { Dry } \\
\text { matter } \\
\text { content } \\
(\%)\end{array}$ & & $\begin{array}{l}\text { Fat } \\
\text { content } \\
(\% \quad p \\
\text { dry } \\
\text { matter) }\end{array}$ & & $\begin{array}{l}\text { Protein } \\
\text { content } \\
(\%)\end{array}$ & & pH & $\begin{array}{l}\text { Breakdown } \\
\text { stress (kPa) }\end{array}$ & $\begin{array}{l}\text { Critical } \\
\text { strain } \\
\text { breakdowı } \\
\text { (rad) }\end{array}$ & \\
\hline FFI & $\begin{array}{l}\text { Very firm, } \\
\text { low-fat }\end{array}$ & $\begin{array}{l}48.00 \\
1.00\end{array}$ & \pm & $\begin{array}{l}25.00 \\
1.00\end{array}$ & \pm & $\begin{array}{l}27.90 \\
0.50\end{array}$ & \pm & $\begin{array}{l}5.55 \pm \\
0.04\end{array}$ & $15.25 \pm 1.23$ & $\begin{array}{l}0.836 \\
0.048\end{array}$ & \pm \\
\hline SI & Soft, low-fat & $\begin{array}{l}40.5 \\
1.00\end{array}$ & \pm & $\begin{array}{l}25.00 \\
1.00\end{array}$ & \pm & $\begin{array}{l}23.3 \\
0.50\end{array}$ & \pm & $\begin{array}{l}5.48 \pm \\
0.28\end{array}$ & $4.34 \pm 0.47$ & $\begin{array}{l}0.814 \\
0.076\end{array}$ & \pm \\
\hline Fh & Firm, high-fat & $\begin{array}{l}48.03 \\
0.94\end{array}$ & \pm & $\begin{array}{l}48.55 \\
1.54\end{array}$ & \pm & $\begin{array}{l}19.48 \\
0.32\end{array}$ & \pm & $\begin{array}{l}5.27 \pm \\
0.01\end{array}$ & $15.56 \pm 2.31$ & $\begin{array}{l}0.348 \\
0.061\end{array}$ & \pm \\
\hline Sh & Soft, high-fat & $\begin{array}{l}35.45 \\
0.17\end{array}$ & \pm & $\begin{array}{l}48.31 \\
0.50\end{array}$ & \pm & $\begin{array}{l}14.06 \\
0.07\end{array}$ & \pm & $\begin{array}{l}5.35 \pm \\
0.02\end{array}$ & $8.02 \pm 1.31$ & $\begin{array}{l}0.273 \\
0.022 \\
\end{array}$ & \pm \\
\hline
\end{tabular}


Table 2. Physico-chemical properties of the aroma compounds

\begin{tabular}{lll} 
& Ethyl propanoate & 2-nonanone \\
\hline Chemical formula & $\mathrm{C}_{5} \mathrm{H}_{10} \mathrm{O}_{2}$ & $\mathrm{C}_{9} \mathrm{H}_{18} \mathrm{O}$ \\
Chemical class & ester & ketone \\
CAS number & $105-37-3$ & $821-55-6$ \\
Molar mass & $102.13 \mathrm{~g} / \mathrm{mol}$ & $142.24 \mathrm{~g} / \mathrm{mol}$ \\
LogP & 1.21 & 2.90 \\
Air/water partition & 9.13 & 1.29 \\
Coefficient $\mathbf{x 1 0}^{3}\left(\mathbf{2 5}^{\circ} \mathbf{C}\right)^{\dagger}$ & $0.892 \mathrm{~g} / \mathrm{cm}^{3}$ & $0.816 \mathrm{~g} / \mathrm{cm}^{3}$ \\
Density & Fruity & Blue, Roquefort \\
Typical odor &
\end{tabular}

${ }^{\dagger}$ calculated value (EPI, 2000, Estimation Programs Interface V3,10: database). 
Table 3. Ranking of mean air/bolus partition coefficients for ethyl propanoate at $35^{\circ} \mathrm{C}$ according to the dilution rate by saliva in the bolus (Dunn method, level of significance set at 5\%). Sub-table a: cheeses $\mathrm{FFl}, \mathrm{Sl} \& \mathrm{Sh}$; sub-table b: cheese Fh. Two groups with no common letters are statistically different at a $5 \%$ level.

a.

\begin{tabular}{lll}
\hline Cheeses FFl, Sl \& Sh & & \\
\hline group & mean $K_{A B}^{\dagger}$ & dilution \\
\hline A & $2.82 \times 10^{-2}$ & pure saliva \\
A & $2.18 \times 10^{-2}$ & $90 \mathrm{~s}-10 \mathrm{p}$ \\
$\mathrm{AB}$ & $1.27 \times 10^{-2}$ & $50 \mathrm{~s}-50 \mathrm{p}$ \\
$\mathrm{B}$ & $1.00 \times 10^{-2}$ & $10 \mathrm{~s}-90 \mathrm{p}$ \\
$\mathrm{B}$ & $0.96 \times 10^{-2}$ & pure cheese \\
\hline
\end{tabular}

b.

\begin{tabular}{lll}
\hline Cheese Fh & & \\
\hline group & mean $K_{A B}^{\dagger}$ & dilution \\
\hline $\mathrm{A}$ & $2.82 \times 10^{-2}$ & pure saliva \\
$\mathrm{AB}$ & $1.62 \times 10^{-2}$ & $90 \mathrm{~s}-10 \mathrm{p}$ \\
$\mathrm{AB}$ & $0.76 \times 10^{-2}$ & pure cheese \\
$\mathrm{AB}$ & $0.62 \times 10^{-2}$ & $10 \mathrm{~s}-90 \mathrm{p}$ \\
$\mathrm{B}$ & $0.55 \times 10^{-2}$ & $50 \mathrm{~s}-50 \mathrm{p}$ \\
\hline
\end{tabular}

N.B.: Each letter corresponds to a group. Two groups with no common letters are statistically different at a $5 \%$ level.

${ }^{\dagger}$ For all cheeses and all dilutions, 3 replicates were performed. 
Table 4. Ranking of mean mass transfer coefficients of ethyl propanaote in the bolus $k_{B}$ at $35^{\circ} \mathrm{C}$ according to the dilution rate by saliva (Dunn method, level of significance set at $5 \%$ ). Sub-table a: firm cheeses ( $\mathrm{FFl}$ and $\mathrm{Fh}$ ); sub-table b: soft cheeses ( $\mathrm{Sl}$ and $\mathrm{Sh}$ ). Two groups with no common letters are statistically different at a $5 \%$ level.

a.

\begin{tabular}{lll}
\hline Firm cheeses & & \\
\hline group & mean $k_{B}(\mathrm{~m} / \mathrm{s})^{\dagger}$ & dilution \\
\hline $\mathrm{A}$ & $2.35 \times 10^{-6}$ & pure cheese \\
$\mathrm{A}$ & $2.22 \times 10^{-6}$ & pure saliva \\
$\mathrm{AB}$ & $1.25 \times 10^{-6}$ & $10 \mathrm{~s}-90 \mathrm{p}$ \\
$\mathrm{AB}$ & $1.22 \times 10^{-6}$ & $90 \mathrm{~s}-10 \mathrm{p}$ \\
$\mathrm{B}$ & $0.27 \times 10^{-6}$ & $50 \mathrm{~s}-50 \mathrm{p}$ \\
\hline
\end{tabular}

b.

\begin{tabular}{lll}
\hline Soft cheeses & & \\
\hline group & mean $k_{B}(\mathrm{~m} / \mathrm{s})^{\dagger}$ & dilution \\
\hline A & $2.22 \times 10^{-6}$ & pure saliva \\
AB & $1.04 \times 10^{-6}$ & $90 \mathrm{~s}-10 \mathrm{p}$ \\
BC & $0.48 \times 10^{-6}$ & pure cheese \\
BC & $0.45 \times 10^{-6}$ & $50 \mathrm{~s}-50 \mathrm{p}$ \\
C & $0.41 \times 10^{-6}$ & $10 \mathrm{~s}-90 \mathrm{p}$ \\
\hline
\end{tabular}

N.B.: Each letter corresponds to a group. Two groups with no common letters are statistically different at a $5 \%$ level.

${ }^{\dagger}$ For all cheeses and all dilutions, 3 replicates were performed. 
Table 5. Experimental and calculated air/bolus partition coefficients for 2-nonanone at $35^{\circ} \mathrm{C}$ according to the dilution rate by saliva

\begin{tabular}{|c|c|c|c|}
\hline Cheese & Dilution & Mean $K_{A B}^{\dagger}$ & Method \\
\hline Saliva & pure saliva & $45.68 \times 10^{-3}$ & PRV \\
\hline \multirow{4}{*}{ FFl } & $90 \mathrm{~s}-10 \mathrm{p}$ & $11.46 \times 10^{-3}$ & $\begin{array}{l}\text { From adapted Buttery } \\
\text { equation }\end{array}$ \\
\hline & $50 s-50 p$ & $2.87 \times 10^{-3}$ & $\begin{array}{l}\text { From adapted } \text { From } \\
\text { adapted } \\
\text { equation }\end{array}$ \\
\hline & $10 \mathrm{~s}-90 \mathrm{p}$ & $1.64 \times 10^{-3}$ & $\begin{array}{l}\text { From adapted Buttery } \\
\text { equation }\end{array}$ \\
\hline & pure cheese & $1.32 \times 10^{-3}$ & PRV \\
\hline \multirow{4}{*}{ Sl } & $90 \mathrm{~s}-10 \mathrm{p}$ & $10.78 \times 10^{-3}$ & $\begin{array}{l}\text { From adapted Buttery } \\
\text { equation }\end{array}$ \\
\hline & $50 s-50 p$ & $2.66 \times 10^{-3}$ & $\begin{array}{l}\text { From adapted Buttery } \\
\text { equation }\end{array}$ \\
\hline & $10 s-90 p$ & $1.52 \times 10^{-3}$ & $\begin{array}{l}\text { From adapted Buttery } \\
\text { equation }\end{array}$ \\
\hline & pure cheese & $1.32 \times 10^{-3}$ & PRV \\
\hline \multirow{4}{*}{$\mathrm{Fh}$} & $90 \mathrm{~s}-10 \mathrm{p}$ & $17.04 \times 10^{-3}$ & $\begin{array}{l}\text { From adapted Buttery } \\
\text { equation }\end{array}$ \\
\hline & $50 \mathrm{~s}-50 \mathrm{p}$ & $4.86 \times 10^{-3}$ & $\begin{array}{l}\text { From adapted Buttery } \\
\text { equation }\end{array}$ \\
\hline & $10 \mathrm{~s}-90 \mathrm{p}$ & $2.83 \times 10^{-3}$ & $\begin{array}{l}\text { From adapted Buttery } \\
\text { equation }\end{array}$ \\
\hline & pure cheese & $2.23 \times 10^{-3}$ & PRV \\
\hline \multirow{4}{*}{ Sh } & $90 \mathrm{~s}-10 \mathrm{p}$ & $10.32 \times 10^{-3}$ & $\begin{array}{l}\text { From adapted Buttery } \\
\text { equation }\end{array}$ \\
\hline & $50 s-50 p$ & $2.52 \times 10^{-3}$ & $\begin{array}{l}\text { From adapted Buttery } \\
\text { equation }\end{array}$ \\
\hline & $10 s-90 p$ & $1.44 \times 10^{-3}$ & $\begin{array}{l}\text { From adapted Buttery } \\
\text { equation }\end{array}$ \\
\hline & pure cheese & $1.25 \times 10^{-3}$ & PRV \\
\hline
\end{tabular}

${ }^{\dagger}$ For pure cheeses and pure saliva, 3 replicates were performed. 


\section{APPENDIX A}

\section{Model for the determination of the Mass Transfer Coefficient}

In the Volatile Air Stripping Kinetic (VASK) method (Lauverjat et al., 2009), the product containing the volatile compound is equilibrated with the headspace air in a closed flask. At time $t=0$, the headspace is stripped with a constant airflow, and the volatile compound concentration in the outlet air is continuously measured by PTR-MS. The volatile concentrations in the product and in the headspace are given by:

$$
\begin{aligned}
& V_{B} \times \frac{d C_{B}}{d t}=-A \times k_{B} \times\left(C_{B}-\frac{C_{A}}{K_{A B}}\right) \\
& V_{A} \times \frac{d C_{A}}{d t}=A \times k_{B} \times\left(C_{B}-\frac{C_{A}}{K_{A B}}\right)-C_{A} \times Q
\end{aligned}
$$

where:

A is the contact area between the air and the product $\left(\mathrm{m}^{2}\right)$,

$V_{B}$ and $V_{A}$ are the volume of the bolus and of the air, respectively $\left(\mathrm{m}^{3}\right)$,

$\mathrm{C}_{\mathrm{B}}$ and $\mathrm{C}_{\mathrm{A}}$ are the concentration of aroma in the product and in the air, respectively $\left(\mathrm{kg} / \mathrm{m}^{3}\right)$,

Q is the air flow rate stripping the headspace $\left(\mathrm{m}^{3} / \mathrm{s}\right)$,

and $K_{A B}$ is the air/bolus partition coefficient $\left(K_{A B}=\frac{C_{A}{ }^{e q}}{C_{B}{ }^{e q}}\right.$ with $K_{A B}=\frac{C_{A}{ }^{0}}{C_{B}{ }^{0}}$ under our experimental conditions).

The mass transfer coefficient $k_{B}$ is determined by fitting the air concentration predicted by the model to the release kinetics obtained by PTR-MS measurements. 